\title{
GREXIT AND BREXIT: RATIONAL CHOICE, COMPATIBILITY, AND COERCIVE ADAPTATION
}

\author{
Steven ROSEFIELDE
}

This article combines a rational choice framework with an analysis of contemporary European Union institutions to elucidate the causes of Grexit and Brexit. It shows that the sustainability of the EU in part or whole in "normal" times depends on member compatibility and coercive adaptation. If members share the same values, including a common vision of transnational governance and a commitment to mutual support (solidarity), the EU should be able to stick together through thick and thin. If, on the contrary, members hold incompatible outlooks on the distribution of transnational powers and solidarity, then the EU will be vulnerable to dismemberment. The EU today is prone to disunion because its members no longer share a common view of mutually acceptable transnational government and policy; powerful members insist upon bending recalcitrant members to their will (coercive adaptation), and participants hold contradictory attitudes towards solidarity on a variety of issues. Winston Churchill and Robert Schuman in the late 1940s hoped that their post-war Europe project would be something more than a "single market"; that it would become the cornerstone of European peace. They appreciated the value of cooperative economy, but considered material benefits icing on the cake. Brexit and Grexit are best seen in this larger perspective underscoring the wisdom of conciliation.

Keywords: Brexit, Grexit, European Union, euro, eurosceptism

JEL classification indices: D86, F34, H63

Steven Rosefielde, Professor at the University of North Carolina at Chapel Hill, Department of Economics. E-mail: stevenr@email.unc.edu. 


\section{TRANSNATIONAL CLUBS}

The European Union can be likened to a transnational club composed of sovereign nations outsourcing some governing powers to club officials. The division of powers between self-regulating members and club officials creates a twolevel control regime intended to harmonise personal (local) and board members (transnational interests). The approach works adequately when club officials and members see eye to eye, but requires mutual accommodation otherwise.

There is no ideal transnational club. Bounded rationality and ethical pluralism permit multiple satisfying arrangements, but no universal best (Simon 1957, 1990, 1991; Tisdell 1996; Rubinstein 1998; Gigerenzer - Selten 2002; Kahneman 2003; Rosefielde - Pfouts 2014). Nonetheless, general competitive individual utility-seeking with learning and permissible taste change provides an instructive benchmark. It requires members to negotiate and renegotiate rules as circumstances dictate so that participants continuously maximise their utility and well-being, including rules of entry, expulsion, withdrawal, and re-entry. The watchword is free choice. Members decide for themselves whether to accept or reject the group consensus. When acquiescence is tolerable, they stay. If it isn't, they leave. ${ }^{1}$

\section{FORMATION AND EVOLUTION OF THE EURO CLUB}

Nation states before World War II never voluntarily surrendered control over their fiscal, monetary, financial, legal, defence, education, social, and foreign policy as part of a package to achieve common goals, even though they participated in international institutions like the League of Nations. The horrors of the war, combined with Cold War politics and the welfare state tide, however, propelled Europe along a novel supranational trajectory with some unintended consequences. On September 19, 1946, Winston Churchill gave a speech in Zurich not only advocating Franco-German rapprochement, but a kind of United States of Europe called a European "Third Way." Churchill can be considered the EU's founder. He also advocated a "Council of Europe" formed thereafter with the assistance of French Foreign Minister Robert Schuman, mandated to create supranational communities on the path to a fully democratic, integrated Union. ${ }^{2}$ The Schuman Declaration of May 9, 1950, reaffirmed the concept in conjunction with the for-

This is how the South defined the United States prior to the Civil War.

The term supranational community was coined by Jean Monnet, Head of France's General Planning Commission. 
mation of the European Coal and Steel Community (ESCS). It proclaimed the European Community as the world's first supranational institution, marking the "birth of modern Europe", and initiating an epoch where intra-European wars were impossible. ${ }^{3}$

Schuman's utopian vision, which can be traced back to France's first socialist, Claude Henri de Rouvroy, comte de Saint-Simon (1760-1825) (On the Reorganization of European Industry, 1814), was the prelude to a succession of developments culminating in today's European Union, including the European Economic Community (EEC), known as the Common Market (1958), the European Community (1967) (together with the European Commission and the European Council of Ministers), the European Council (1974), the European Monetary System (1979), the European Parliament (1979), the Schengen Agreement (1985) which opened intra-union borders, the Single Market Act (1986), the Maastricht Treaty (1993) founding the European Union (EU), ${ }^{4}$ and the European Monetary Union (2002), which inaugurated the euro. On December 1, 2009, the Lisbon Treaty entered into force and reformed many aspects of the EU. In particular, it changed the legal structure of the European Union, merging the EU three pillars system into a single legal entity, ${ }^{5}$ creating a permanent President of the European Council, and strengthening the High Representative of the Union for Foreign Affairs and Security Policy. ${ }^{6}$

Membership in Churchill's and Schuman's club was open to any European nation willing to participate in a supranational community on the path to discovering whether the group could devise a satisfactory fully democratic federal entity. Belgium, France, Germany, Italy, Luxembourg, and the Netherlands accepted the agenda in 1958 and seem content with their decision with the possible

3 In 2012, the EU received the Nobel Peace Prize for having "contributed to the advancement of peace and reconciliation, democracy, and human rights in Europe."

4 The European Union's seven principal decision-making bodies are the European Council, the Council of the European Union, the European Parliament, the European Commission, the Court of Justice of the European Union, the European Central Bank, and the European Court of Auditors.

5 The term three pillars refer to (1) Economic, social and environmental policies performed by the European Community (EC), the European Coal and Steel Community (ECSC, until its expiry in 2002), and the European Atomic Energy Community (EURATOM); (2) Foreign policy and military under the jurisdiction of the Common Foreign and Security Policy (CFSP), and (3) Judicial and police matters undertaken Police and Judicial Co-operation in Criminal Matters (PJCCM).

6 The military of the European Union comprises the various cooperative structures that have been established between the armed forces of the member states, both intergovernmentally and within the institutional framework of the union; the Common Security and Defence Policy (CSDP) branch of the Common Foreign and Security Policy (CFSP). 
exceptions of the Netherlands and France, which are under pressure for Nexit and Frexit. ${ }^{7}$ They were pleased both with the Common Market and subsequent efforts to expand the political, social, juridical, police, foreign, and defence policy aspects of the union. They all want to continue the search for an amicable united European federative state with supranational characteristics, and perhaps without them (super-state). ${ }^{8}$

Great Britain, Ireland, and Denmark joined the founding six members in 1973. The British and Danish publics were Eurosceptics from the outset. Their leaders were attracted to the economic benefits of tariff elimination in a common market, but were more ambivalent about deeper economic and political integration, including subsequent monetary union, proposals for supranational regulation fiscal, political, social, juridical, police, foreign affairs, and defence matters. ${ }^{9}$ Britain and Denmark refused to join the euro zone.

The policy area of defence is principally the domain of nation states. The main military alliance in Europe remains the intergovernmental North Atlantic Treaty Organisation (NATO), which presently includes $22 \mathrm{EU}$ member states together with 4 non-EU European countries (Albania, Iceland, Turkey, and Norway) as well as the United States and Canada. The development of the CSDP with regard to the existing role of NATO is a contentious issue. The military form of European integration, however, has intensified in the beginning of the $21 \mathrm{st}$ century, bringing about the deployment of numerous CSDP operations and the establishment of EU battle groups. The latter, however, have never been engaged in operations, and other, recent examples of military integration such as the European corps, gendarmerie force, and air transport command are intergovernmental, and outside the institutional framework of the union.

7 A poll by the Pew Research Center in June 2016, before the British referendum, found the Dutch to have a $46 \%$ negative view of the European Union, less than the $51 \%$ of their population was found to have a positive view towards it. The Pew Research Center poll found $61 \%$ of the French population held an unfavourable view of the EU, second only to Greece's $71 \%$, with the UK at $48 \%$.

$8 \quad$ Margaret Thatcher warned against an EU super-state in 1988 (Palmer 1988).

9 The governing bodies of the EU's supranational governance tier are the European Parliament, Council of the European Union, the European Commission, the European Council, European Central Bank, the Court of Justice of the European Union, and the European Court of Auditors. Supranational bodies have exclusive competence over (1) the "customs union", (2) competition policy, (3) euro zone (EZ) monetary power, (4) a common fisheries policy, (5) a common commercial policy, and (6) conclusion of certain international agreements. They also have the right to shared competence in (7) the internal market, (8) social policy for aspects defined in the treaty, (9) agriculture and fisheries, excluding the conservation of marine biological resources, (10) environment, (11) consumer protection, (12) transport, (13) trans-European networks, (14) energy, (15) the area of freedom, security, and justice, (16) common safety concerns in public health aspects defined in the treaty, (17) research, development, technology, and space, (18) development, cooperation, and humanitarian aid, (19) coordination of economic and social policies, and (20) common security and defence policies. Additionally, supranational bodies enjoy supporting competence in (21) protection 
Greece and Spain became EU members in the 1980s, both aware of efforts to construct a European monetary union, open borders, and create a "single market". They and the 15 other countries that signed on after the Soviet Union's demise primarily sought economic benefits, but also agreed to explore the federative possibilities urged by the founding six under the slogan "more Europe". The details of federation with supranational characteristics remain as elusive today as they were at the outset of the project. What will be the characteristics of an all-union trans-nationalised culture, and who will rule at the end of the day? Will there be a hegemon, or will democracy prevail?

\section{Fiscal union}

Proponents of "more Europe" are understandably loath to offer specifics about the distribution of real authority, but nonetheless have pressed this agenda under the banner of fiscal union. The slogan "more Europe" for the moment means perfecting the single market, establishing a lender of last recourse for the euro zone, and complementing monetary union with a unified transnational fiscal system that will supplant aspects of national taxing authority and strengthen supranational public policymaking. Most macroeconomic theorists believe that a federation will empower sound macroeconomic management and restore prosperity (De Grauwe 2010; Rosefielde - Razin 2012a, 2012b; Sargent 2012; Rosefielde 2015; Razin - Rosefielde 2016). It promises a generally competitive, optimally macro-managed economically integrated system with "inclusive" sensibilities (Tirole 2015; Dallago forthcoming).

\section{EUROSCEPTISM}

Eurosceptics don't deny the virtues of economic efficiency, stability, integrated macroeconomic management, coordinated supranational public policy, and social humanism. They acknowledge the microeconomic benefits of widened markets, free trade, and finance, but contend that Eurocrats cannot deliver what they promise and have hidden agendas (Mundell 1961, 1963; Fleming 1962; McKinnon 1963). They believe that full costs will exceed the gains. Specifically, they assert that Brussels and Berlin abuse their decision-making powers in their

and improvement of human health, (22) industry, (23) culture, (24) tourism, 25) education, youth sport, and vocational training, (26) civil protection (disaster prevention), and (27) administration. 
own interest and seek to undemocratically expand their control not only over the EU economy, but comprehensively over all dimensions of members' political, social, cultural, foreign, and defence activities (Bolton 2016). They recognise that Brussels and Berlin portray themselves as skilful benevolent technocrats, but contend that "more Europe" insiders act primarily on their own behalf at others' expense. ${ }^{10}$

Eurosceptics also maintain that members like Britain, which had hoped to cherry pick, taking the good and avoiding the bad by insisting on strong national autonomy within a trans-nationalising framework, are discovering that this is a losing game. The "more Europe" camp is gradually imposing its will on the EU, forcing dissenters to accept the new normal, or leave. There are no longer any prospects for "less Europe" to accommodate club members who prefer a weaker form of association. Transnationalism and supranationalism in the eyes of Eurosceptics have become hollow concepts.

They see the European transnational economic union as a failing project, compounded by democratic disempowerment (Dallago 2016a; Dallago et al. 2016). The Greeks are particularly adamant on this point. The British by contrast place the emphasis the other way round. They don't want to be ruled by Brussels and Berlin, and are less concerned about economics. A large segment of population is disgruntled by EU economic rules and regulations, but the pain is less acute than in Greece. The issue of democratic disempowerment voiced by Greece and Britain has been widely documented in the political science literature where the problem is characterised as a "democratic deficit" (Piattoni 2016). The term taken seriously by many political scientists has gained little traction among economists, but deserves attention when trying to comprehend Grexit and Brexit. British voters came to believe that the EU bureaucracy is opaque, and British interests are overwhelmed by those of other EU members, especially Germany. A nonpartisan analysis concluded that approximately $60 \%$ of all legislation enacted by Britain's Parliament was dictated, in whole or in part, by decisions already reached by Brussels bureaucrats or EU diplomats (Bolton 2016; Dallago 2016 a).

10 Gretschmann (2016): "Both in economic and political terms, the EU is on life support. Its former attractiveness as an economic powerhouse, a political 'soft power' and a much appreciated social model seems to be waning in the face of the Eurozone troubles and the political and military challenges at its borders." 


\section{Empty promises}

Eurosceptics might grin and bear lost national political and economic autonomy if the European Union and the euro zone were uniformly prosperous. ${ }^{11}$ However, there is no convincing economic evidence that all club members have benefited (Rosefielde 2016). This seems counter-intuitive because theory stresses the benefits of liberalisation, free labour and capital mobility, outsourcing, technology transfer, and globalisation (Razin - Rosefielde forthcoming). Many prominent economists at the time of Brexit insisted that it was irrational for Britain to withdraw from the club (e.g. Giles 2016). However, there is more to economics than optimally competitive utility-seeking. Bounded rationality and power often generate and entrench undeserving winners and losers.

Moreover, the economic costs of exiting are easily overstated by ignoring alternative opportunities. Much can be accomplished in all these regards without the single market as the experiences of China, Vietnam, India, and Israel attest (Razin - Rosefielde forthcoming). Moreover, the economic benefits of club membership have steadily diminished. EU growth rates have been declining asymptotically toward zero since the UK and Denmark joined the European Community in 1973 (Eurosclerosis), with the exception of the short-lived growth spurt 2000-2008 accompanying the euro's adoption (Maddison 2003). The EU has been afflicted by secular stagnation since 2008 and double digit member unemployment is widespread. Real wages have fallen precipitously, income and wealth inequality have burgeoned, and the EU has underperformed the United States (Piketty 2014). All these negatives can be blamed on other forces, or it always can be argued that the EU saved members from even worse fates, but it is also easily understood why Eurosceptics deem these claims excuses. Klaus Gretschmann reminds us that the EU regulators extended their reach without cogent justification. ${ }^{12}$ Overregulation is wasteful by definition and often impedes growth by warping and disincentivising innovation, technological progress, entrepreneurship, and investment. Over-regulation devitalises national economies; hegemonic supranational over-regulation compounds the problem by adding a second level of obstruction and waste.

11 Greer - Jarman (2016): "The whole apparatus of fiscal governance and conditional lending... is entrenched in law, treaties, and member state constitutions, and in theory subjects member states to a broad, deep, and automatic mechanism that shapes their fiscal and therefore public policies."

12 Gretschmann (2016): "The EU has turned into a legislative machine trying to interpret her fields of competence ever more widely. Ceaselessly, the Commission is working on weaving an ever closer web of harmonized European laws and regulations - the result thereof, the 'acquis communautaire', is presently estimated to comprise some 100,000 printed pages." 


\section{GREXIT}

Greece provides an object lesson on complexities swept under the rug by assuming that competition and solidarity heal all wounds under prevailing Lisbon Treaty arrangements. Athens was both an early beneficiary and victim of the Maastricht Treaty. It joined the euro zone in 2001 and immediately enjoyed an investment bonanza as EU and foreign funds flooded the GIIPS (Greece, Italy, Ireland, Portugal, and Spain) in response to an implied euro zone creditworthiness guarantee (Rosefielde - Razin 2012). Hard asset prices, especially land and property values skyrocketed. Per capital GDP rose $25 \%$, narrowing the gap with the EU average in 2001-2008. Unemployment, especially among the youth, declined significantly. The Greek government capitalised on the strong euro and the implied creditworthiness guarantee to amass a huge national debt, much of it owed to foreigners. A large portion of these capital inflows funded an expansion of public service sector jobs, increased salaries, and benefits. Athens and German investors were both delighted until the bubble burst.

The global financial crisis of 2008 reversed the process. Suddenly, Greece was no longer creditworthy and Germany demanded that Athens adopt "austere" fiscal measures to assure debt repayment to German banks and private investors. Greek leaders appealed for debt relief and were accommodated four times (2010, 2012, 2015 and 2016), but to little avail. By 2012, Greeks' per capita real GDP was the same as in 2001 and had fallen to $74 \%$ of the EU average. Employment gains vanished and youth unemployment rose above 50\% (Figure 1), despite a sharp austerity impelled internal devaluation (Tartar 2015).

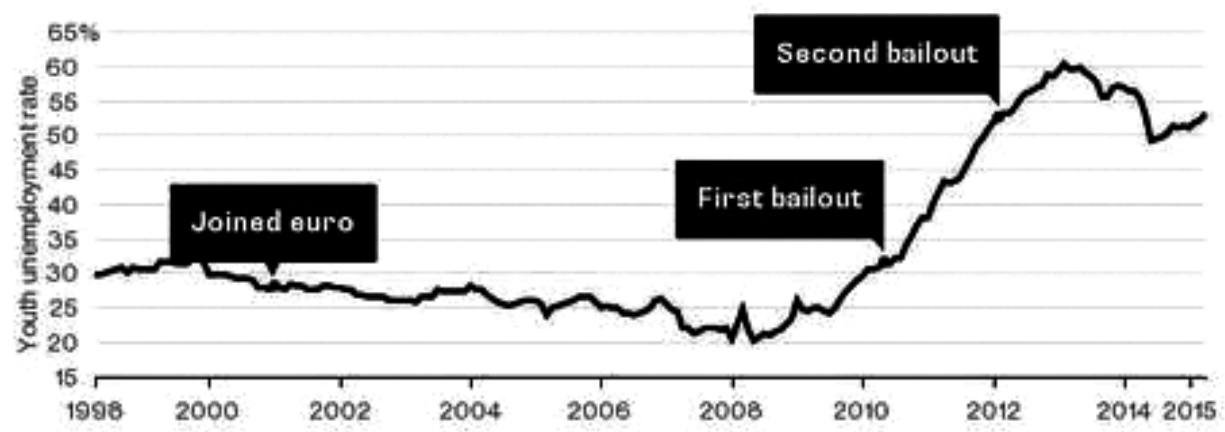

Figure1. Labour Gains Quickly Erased. Joblessness among young Greeks fell by 8 percentage points in the first seven years with the euro before sky-rocketing by more than 40 percentage points.

Source: Eurostat.

Note: Youth unemployment refers to people under 25 years of age. 
The hardship inflicted by this rollercoaster ride prompted a democratic revolt. On July 5, 2015, 62\% of Greeks voted to reject an EU, ECB, and IMF backed debt relief package, effectively opting for Grexit. If the Greek people had their druthers, their leaders would have cancelled Greece's club membership. Prime Minister Alexis Tsipras however decided instead that discretion was the better part of valour. He chose to sign a deal worth EUR 86 billion over three years laden with conditions such as tax hikes and pension reforms, considered by critics to be so tough that social media buzzed with talk of a coup d'etat.

Tsipras's capitulation in the face of a popular mandate can be variously interpreted. ${ }^{13}$ Some construe it to mean that the Prime Minister grasped the indispensability of euro zone membership regardless of the intermediate term costs. Some portrayed it as a "sellout" that sacrificed the public good for the benefit of powerful insiders, while others attributed his action to the risk of devastating punitive actions by the ECB. The latter interpretation is the most interesting from the standpoint of appraising the EU's future. It points to the possibility that the EU's merit depends not only on rational free choice, but on the risks of hegemonic economic and political coercion.

\section{Supranational capital flight}

Greece may have been brought to its knees by capital flight of a novel sort that took most observers by surprise. Greeks began withdrawing unsustainable amounts of euro deposits from private banks because they correctly feared that the ECB might cut off currency supplies in an attempt to jawbone Tsipras into accepting structural reform. Capital flight traditionally has been associated with hot money fleeing currencies ripe for devaluation. The Greek case was different. Euro devaluation wasn't an issue. Depositors fled Greek banks because they wanted to retain access to the euro, not because they feared euro devaluation. They recognised that the ECB might curtail euro access and that Greek banks might collapse if a run-for-the-liquid-euro couldn't be accommodated because banks assets were illiquid. ${ }^{14}$

13 Polls taken before July 15 showed a plurality of Greeks favoured remaining in the EU. Although, Greek voters knew that a vote against the EU, ECB, and IMF backed debt relief package could be construed as a vote for Grexit if creditors stuck to their guns, earlier poll data gave Tsipras the wiggle room he needed to capitulate on the debt and Grexit. This was the course that he chose.

14 The literature on borrowing (incentive compatible) constraints is based on Holmstrom -Tirole (1997). One basic mechanism outlined in recent currency crisis models is where unhedged foreign currency liabilities play the key role in causing and transmitting crises. One of the first 
The phenomenon can be labelled supranational capital flight because it is a logical consequence of the EU governance scheme, which allows national banks to operate with a currency that national authorities do not control. Rational actors foreseeing a looming confrontation between supranational and national authorities will always find it costless to take their money and run, holding euros in cash, redepositing them in Helsinki or purchasing other currencies.

This vulnerability and the difficulty of quickly re-adopting the drachma were invisible as long as cooperation and consensus were mandatory. ${ }^{15}$ Shutting the

models to capture this joint problem was presented in Krugman (1999) and Schneider -Tornell (2004). In this approach, firms suffer from a currency mismatch between their assets and liabilities: their assets are denominated in domestic goods, and their liabilities are denominated in foreign goods. Then, real exchange rate depreciation increases the value of liabilities relative to assets, leading to deterioration in firms' balance sheets. Chang - Velasco (2001) show the vicious circle between bank runs and speculative attacks on the currency. On the one hand, the expected collapse of the currency worsens banks' prospects, as they have foreign liabilities and domestic assets, and thus generates bank runs. On the other hand, the collapse of the banks leads to capital outflows that deplete the reserves of the government, encouraging speculative attacks against the currency. Accounting for the circular relationship between currency crises and banking crises complicates policy analysis. For example, a lender-of-last-resort policy or other expansionary policy during a banking crisis might backfire as it depletes the reserves available to the government, making a currency crisis more likely, which in turn might further hurt the banking sector that is exposed to a currency mismatch. See De Grauwe - Ji (2013) for the lender-of-last-resort role, and Razin (2015) for a survey.

15 Bulow - Rogoff (2015) write: "It is true that a major early motivation for the EU to lend to Greece was to subsidize its banks, but it is not true that Greece's creditors were taking money out of the country, at least until the Greeks chose to postpone or stop meeting the terms of its second bailout deal in the second half of 2014. Europe continued to provide cash inflows to Greece until that time, on top of the banking system support it still provides, and arguably does not really expect to be a net receiver of very much if any money over the next few years (at the very least). The bailout deals negotiated with Greece were meant to provide it with the cash needed to ease the transition from running primary deficits in its heavy borrowing years and to help keep its banks running and its private creditors at bay. The problems that Greece faces are due to a loss of confidence in the state, not only by foreign private investors but also by Greece's own citizens. Indeed, the latter have withdrawn over a hundred billion euros from the banking system since the onset of the crisis in early 2010. While Europe has replaced much of this money through Target2 loans (now primarily 'Emergency Liquidity Assistance') the Greek banks have also been weakened by the $33.5 \%$ of their private loans that are nonperforming, reducing their capacity to take on new risky loans. It is partly for this reason, as well as because of the losses Greek banks suffered in 2012 on their holdings of Greek Government Bonds, that a significant part of the new money that Greece received over the past five years had to be used to recapitalise Greek banks. 
ECB spigot (TARGET 2) was unimaginable. ${ }^{16}$ Now that the genie is out of the bottle, however, it can be assumed that coercive methods, including euro zone supranational capital flight could be invoked whenever debt to GDP ratios expand and the danger of confrontation within EU governance structures looms.

\section{BREXIT}

Britain's decision to cancel its membership in club EU is only obliquely connected with Grexit. Voters were aware of Greece's plight, but Britain was not a euro zone member. Supranational capital flight therefore was irrelevant. Nor was Britain over-indebted by the standards of other EU members. ${ }^{17}$ It post-financial crisis growth and employment were the best in the EU. Some argued that Britain's macro performance would have been more vibrant if it weren't entangled with the EU. However, the principal grievance motivating referendum voters was forced public goods substitution, including control over migrants and refugees. Eurosceptics felt that Eurocrats restricted local public policy choice, generated strong downward wage pressure, exacerbated involuntary unemployment, intensified unwelcome foreign labour migration (Dallago - McGowan 2016), in-

Whereas the EU has actually been a net provider of funds to Greece since the beginning of the crisis, this is not to say that its motivation has been entirely charitable. Greece has been able to combine the threat of default (which would create an unknown and potentially massive risk for the EU), a promised commitment to economic reforms that would put it on the road to self-sufficiency, and its 'too small to fail' status to gain extraordinary financial support. Over time, the risks of 'Grexit' - Greece leaving the euro - while still unknown, appear to have lessened for most observers. At the same time, the Greeks have recently elected a party seemingly intent on rolling back some of the country's hard-won economic reforms, negotiations have become harder. Nevertheless, it seems unlikely that in any deal Greece would be asked to pay back as much cash as it receives in net subsidies from the EU, at least for a long time to come." (www.voxeu.org/article/modern-greek-tragedy)

16 TARGET2 (Trans-European Automated Real-time Gross Settlement Express Transfer System) is the real-time gross settlement (RTGS) system for the euro zone, and is available to non-euro zone countries as well. There is no upper or lower limit on the value of payments. This means that the ECB had an instrument in place to prevent Greek Euro capital flight if it had chosen to do so. Instead, it permitted Greece and others to receive long-term low interest credit in lieu of instantaneous settlement. This technically is what gave the ECB the power to jawbone the Greek government over its bank capital flight. The ECB could have approached the problem earlier on a prudential basis, but for reasons unknown to the author, didn't.

17 The UK's debt to GDP ratio in 2015 was 90.6 percent. Portugal's debt to GDP ratio in the same year was 129 percent. The figure includes intra governmental debt is substantially lower than the American counterpart figure. CIA World Factbook (https://www.cia.gov/library/publications/the-world-factbook/geos/uk.html). 
creased terrorist risk, and drew them too deeply into Germany's political orbit (Mills - Rosefielde 2016). Moreover, they argued that Eurocrats were unelected and unresponsive to the British people's will. ${ }^{18}$

It can be counter-argued that British voters were ill informed about these issues in varying degrees, but truth is peripheral to the larger question of EU survivability. Advocates of "more Europe" displayed an inability to defuse grievances essential for the survival of the Greater Europe project.

\section{One country, two systems}

Brussels and Berlin are unlikely to significantly accommodate demands for "less Europe" anytime soon. Their convictions are deeply held. Nonetheless, the time seems at hand for an intra-EU discussion of a third way. The Chinese concept of "one country, two systems" employed by Beijing to accommodate Hong Kong may provide a fruitful institutional compromise. Advocates of strong supranationality, including a super-state with token transnational characteristics, can be likened to Beijing; club members desiring "less Europe" to Hong Kong. Both systems can share a mutually agreeable core set of supranational arrangements, adjusted to reflect local needs. EU strong supranationalists in this framework would be free to negotiate more comprehensive common rules and a unified monetary-fiscal transnational accord among themselves while weak supranationalists either abided by the common core, or narrowed it to taste, and members of both EU groups were permitted to switch sides. Europhoric and Eurosceptic countries under this scheme could modify the terms of membership to suit their changing needs without having to ponder exiting the club.

\section{Other considerations}

The one country, two systems formula also provides a suggestive framework for dealing with non-economic issues. The scope of the EU concerns broadened in 1967 to include political, social, defence, and foreign policy when the club became the European Community. The interests of the six founding members were sufficiently congruent to make this possible, and the same principles were ap-

18 These issues weren't bolts from the blue. They appear to the author to have come to a head because of mounting concerns about terrorism, refugees, and immigration; the resentment of local authorities to Brussels' encroachment, the political determination of Brexit advocates, and mounting antagonism between EU winners in London and loser everywhere else in England. 
plied as membership grew, facilitated by the demise of the Soviet Union and the breakup of its empire. The diversity of interest among club members proved manageable during the halcyon days, but the façade of unanimity is wearing thin today as a consequence of mounting global terror threats, refugee crises, ethnic and religious pressures, and Putin's annexation of Crimea. The Visegrad four, for example, don't want to compromise their national identities, a concern easily accommodated in a less doctrinaire "united Europe".

\section{World order}

Winston Churchill and Robert Schuman hoped that their new post-war Europe project would be something more than a "single market"; that it would become the cornerstone of European peace and perhaps the kernel of a new World Order. They appreciated the value of a cooperative economy, but considered material benefits icing on the cake. The United States and Germany still want the EU to serve this vital function, but may have forgotten that mutual conciliation within the union is the sine qua non for lasting success.

\section{CONCLUSION}

The EU today is prone to conflict and disunion because its members, in response to changing global realities, no longer share a common view of mutually acceptable transnational government and policy; powerful members insist upon bending recalcitrant members to their will (coercive adaptation), and participants hold contradictory attitudes towards solidarity on a variety of economic, political, social, and cultural issues. Brussels and Berlin are likely to redouble their efforts for "more Europe" rather than meaningfully accommodate the disaffected and may well muscle their way forward Dallago (2016b, 2016d); however, a more flexible plan B analogous to China's "one country, two systems" scheme that accommodates special needs within a broader union may well prove more effective. Any virtuous solution requires members to negotiate and renegotiate rules as circumstances dictate so that participants continuously maximise their utility and well-being, including rules of entry, expulsion, withdrawal, and re-entry. The watchword is democratic free choice for all anti-authoritarian clubs and, by extension, the construction of a larger and harmonious World Order. 


\section{REFERENCES}

Bolton, J. (2016): Brexit Victory is a True Populist Revolt. American Enterprise Institute, June 24, 2016. http://www.aei.org/publication/brexit-victory-is-a-true-populist

Bulow, J. - Rogoff, K. (2015): The Modern Greek Tragedy. CEPR Vox, June 10, 2015.

Chang, R. - Velasco, A. (2001): A Model of Financial Crises in Emerging Markets. Quarterly Journal of Economics, 116(2): 489-517.

CIA World Factbook, https://www.cia.gov/library/publications/the-world-factbook/geos/uk.html

Dallago, B. (2017): Europhoria and its Aftermath. In: Rosefielde, S. (ed.): Western Economic Stagnation and Social Turmoil: Lessons for Asia. Singapore: World Scientific Publishers (forthcoming).

Dallago, B. (2016b): The Crisis, the Monetary Union, and Migration. In: Dallago, B. - McGowan, J. (eds): Crises in Europe in the Transatlantic Context: Economic and Political Appraisals. London: Routledge, pp. 1-18.

Dallago, B. (2016c): Eurozone: from Distress to Deeper Integration? In: Dallago, B. - McGowan, J. (eds): Crises in Europe in the Transatlantic Context: Economic and Political Appraisals. London: Routledge, pp. 51-68.

Dallago, B. (2016d): The Progressive Rift of the Eurozone: Risks and Remedies. Singapore Economic Review, forthcoming.

Dallago, B. - Guri, G. - McGowan, J. (eds) (2016): A Global Perspective on the European Economic Crisis. London: Routledge.

Giles, C. (2016): Brexit in Seven Charts - the Economic Impact. Financial Times, June 27, 2016.

De Grauwe, P. (2010): The Greek Crisis and the Future of the Eurozone. The Structural Problem in the Eurozone is Created by the Fact that the Monetary Union is not Embedded in a Political Union. Eurointelligence, 11.03.2010.

De Grauwe, P. - Ji, Y. (2013): Self Fulfilling Crises in the Eurozone: An Empirical Test. Journal of International Money and Finance, 34(April): 15-36.

Fleming, M. (1962): Domestic Financial Policies under Fixed and Flexible Exchange Rates. IMF Staff Papers 9 (November): 369-379.

Gigerenzer, G. - Selten, R. (2002): Bounded Rationality. Cambridge: MIT Press.

Greer, S. - Jarman, H. (2016): Reinforcing Europe's Failed Fiscal Regulatory State. In: Dallago, B. - Guri, G. - McGowan, J. (eds): A Global Perspective on the European Economic Crisis. London: Routledge, Chapter 8.

Gretschmann, K. (2016): The EU in Stormy Seas: Beginning of the End or End of the Beginning. In: Dallago, B. - Guri, G. - McGowan, J. (eds): A Global Perspective on the European Economic Crisis. London: Routledge, Chapter 3, pp. 33-47.

Holmstrom, B. -Tirole, J. (1997): Financial Intermediation, Loanable Funds, and the Real Sector. Quarterly Journal of Economics, 112(3): 663-691.

Kahneman, D. (2003): Maps of Bounded Rationality: Psychology for Behavioral Economics. The American Economic Review, 93(5): 1449-1475.

Krugman, P. (1999): Balance Sheets, the Transfer Problem, and Financial Crises. International Tax and Public Finance, 6: 459-472.

Maddison, A. (2003): The World Economy: Historical Statistics. OECD. http://www.ggdc.net/maddison/Historical_Statistics/horizontal-file_03-2009xls. Statistics on World Population, GDP and Per Capita GDP 1-2006AD. (last update: March 2009, horizontal file; copyright Angus Maddison).

McKinnon, R. (1963): Optimum Currency Areas. American Economic Review, 53(4): 717-725.

Mills, Q. - Rosefielde, S. (2016): The Trump Phenomenon and Future US Foreign Policy. Singapore: World Scientific Publishers. 
Mundell, R. (1961): A Theory of Optimum Currency Areas. American Economic Review, 51(4): 657-664.

Mundell, R. (1963): Capital Mobility and Stabilization Policy under Fixed and Flexible Exchange Rates. Canadian Journal of Economic and Political Science, 29(4): 475-485.

Palmer, J. (1988): Thatcher Sets Face against United Europe. Margaret Thatcher's Speech to the College of Europe: 'The Bruges Speech'. The Guardian, September 21, 1988.

Piattoni, S. (2016): Institutional Innovations and EU Legitimacy after the Crisis. In: Dallago, B. - McGowan, J. (eds): Crises in Europe in the Transatlantic Context: Economic and Political Appraisals. London: Routledge, pp. 119-136.

Piketty, T. (2014): Capital in the Twenty-First Century. Cambridge MA: Harvard University Press.

Razin, A. (2015): Understanding Global Crises: An Emerging Paradigm. Cambridge: MIT Press.

Razin, A. - Rosefielde, S. (2016): The European Project after Greece's Near Default. Israel Economics Journal, forthcoming.

Razin, A. - Rosefielde, S. (2017): Israel and Global Developments 1990-2015: Riding with the Global Flows and Weathering the Storms. In: Ben-Bassat, A. - Grunau, R. - Zussman, A. (eds): Israel Economy in the 21st Century. Cambridge: MIT Press, forthcoming.

Rosefielde, S. (2015): Secular Crisis: The Mundell-Fleming Trilemma and EU De-Legitimation. In: Dallago, B. - McGowan, J. (eds): Crises in Europe in the Transatlantic Context: Economic and Political Appraisals. London: Routledge. pp. 71-83.

Rosefielde, S. (2016): The European Project: Moving Forward with Dry Eyes. In: Dallago, B. Guri, G. -McGowan, J. (eds): A Global Perspective on the European Economic Crisis. London: Routledge, pp. 21-32.

Rosefielde, S. - Pfouts, R. W. (2014): Inclusive Economic Theory. Singapore: World Scientific Publishers.

Rosefielde S. - Razin, A. (2012a): A Tale of a Politically-Failing Single-Currency Area. Israel Economic Review, 10(1): 125-138.

Rosefielde, S. - Razin, A. (2012b): What Really Ails the Eurozone? Faulty Supranational Architecture. Contemporary Economics, 6(4): 10-18.

Rubinstein, A. (1998): Modeling Bounded Rationality. Cambridge: MIT Press.

Sargent, T. (2012): Nobel Lecture: United States Then, Europe Now. Journal of Political Economy, 120(1): $1-40$.

Schneider, M. - Tornell, A. (2004): Balance Sheet Effects, Bailout Guarantees and Financial Crises. Review of Economic Studies, 71(3): 883-913.

Simon, H. A. (1957): Models of Man: Social and Rational - Mathematical Essays on Rational Human Behavior in a Social Setting. New York: John Wiley and Sons.

Simon, H. A. (1990): A Mechanism for Social Selection and Successful Altruism. Science, 250(4988): 1665-1668.

Simon, H. (1991): Bounded Rationality and Organizational Learning. Organization Science, 2(1): $125-134$.

Tartar, A. (2015): Here's What Membership in the Euro Did for Greece. Bloomberg, July 17, 2015.

Tirole, J. (2015): Country Solidarity in Sovereign Crises. American Economic Review, 105(8): 2333-2363.

Tisdell, C. (1996): Bounded Rationality and Economic Evolution: A Contribution to Decision Making, Economics, and Management. Cheltenham, UK: Brookfield. 